This is an electronic reprint of the original article. This reprint may differ from the original in pagination and typographic detail.

Author(s): Saarinen, Taina; Nikula, Tarja

Title: Implicit policy, invisible language: Policies and practices of international degree programmes in Finnish higher education

Year: $\quad 2013$

Version:

Please cite the original version:

Saarinen, T., \& Nikula, T. (2013). Implicit policy, invisible language: Policies and practices of international degree programmes in Finnish higher education. In A. Doiz, D. Lasagabaster, \& J. M. Sierra (Eds.), English-Medium Instruction at Universities: Global Challenges (pp. 131-150). Multilingual Matters. https://doi.org/10.21832/9781847698162-011

All material supplied via JYX is protected by copyright and other intellectual property rights, and duplication or sale of all or part of any of the repository collections is not permitted, except that material may be duplicated by you for your research use or educational purposes in electronic or print form. You must obtain permission for any other use. Electronic or print copies may not be offered, whether for sale or otherwise to anyone who is not an authorised user. 


\title{
Manuscript:
}

\section{Implicit policy, invisible language: policies and practices of international degree programmes in Finnish higher education}

\author{
Taina Saarinen and Tarja Nikula
}

\author{
submitted to \\ English-medium instruction at university worldwide: \\ Challenges and ways forward
}

eds. Aintzane Doiz, David Lasagabaster, Juan Manuel Sierra (Multilingual Matters)

\section{Introduction}

Internationalisation of higher education has become increasingly an issue since the late 1980s, both in Finland and elsewhere (Teichler, 2004). This internationalisation development places Finland in a similar situation with other non-Anglophone countries (such as the Netherlands in Wächter \& Maiworm's 2008 study), which resort to offering programmes in English to attract international students (see also Hughes, 2008). This phenomenon is particularly visible in countries with small national languages, while countries such as Germany and France seem to have been more reluctant to initiate English language instruction in higher education (Ammon \& McConnell, 2002). International study has also become a major global economic commodity over the last decades, with a turnover that is calculated in billions of dollars (Coleman, 2006).

When 'globalisation' or 'internationalisation'1 as phenomena extending the boundaries of nation states and their national languages, and entering their systems of education are discussed, we would expect to see language featured explicitly. However, this does not seem to be the case: language appears more or less invisible when internationalisation and globalisation of higher education are discussed (Saarinen, forthcoming). While our social realities are increasingly multilingual - or in some countries, such as the United Kingdom, characterised by what Vertovec (2007) calls super-diversity- the internationalisation strategies of higher education and their degree programme level implementations appear monolingual, or in some cases without specifying any particular language.

Alexander (2008) divides international programmes into three broad groups, depending on their use of the foreign (usually English) language. The replacement type refers to English being used systematically throughout the programme by students and staff alike; Finland represents this type. In the cumulative type the use of the foreign language increases gradually, as proficiency is assumed to improve simultaneously (as apparently takes place in 
the Polish higher education system). In the additional type, the foreign language is used to facilitate the students' transition to courses in the local language; Germany is mentioned as an example.

The international programmes usually involve culturally and linguistically heterogeneous student populations, with varying levels of proficiency in English and experience with English-medium instruction (EMI). This heterogeneity does not seem to be a concern at the level of implementation where, as Hellekjær (2010: 233) puts it, it is often taken for granted that lecturers and students will have few difficulties in operating in English. However, as for example Dafouz and Núñez (2010) show, teachers' performance may be impoverished in their lingua franca, with possible implications both for pedagogical practice and learning outcomes and also students may find learning through English demanding (e.g. Airey \& Linder, 2006; see also Cots and Doiz \& al. in this volume). It thus seems that despite the strong position of English as the instructional language, it is rarely problematised at the outset, and the questions of language mastery or the effects of teaching in English on content learning are rarely discussed (Saarinen, forthcoming). We analyse this apparent paradox by using Finnish higher education as a case in point, with particular attention to the role that 'language' has in the past and present internationalisation policy of Finnish higher education, explicitly or implicitly.

\section{Data and approach}

The data consist, firstly, of text documents such as website degree descriptions for international degree programmes $(\mathrm{N}=44)$. The website data is collected from two universities and two polytechnics ${ }^{2}$ in Finland. The degree programme descriptions form the primary textual data, supported by analysis of national level policy documents in the form of internationalisation strategies for higher education (three documents from 1987-2009).

Additionally, pilot interviews with university staff and students $(\mathrm{N}=4)$ and a student narrative from one university, all concerning the internationalisation of higher education, are also used. Three of the interviews were conducted in Finnish and one in English; also the student narrative was written in English. One interview took place with a university level student affairs administrator; one with a faculty level international affairs administrator; one with a faculty janitor; and one with an international degree student. An additional written student narrative from an international degree student was also used; the narrative was written in English. The interviews lasted from 35 minutes to 85 minutes, and were conducted using a semi-structured interview frame. Throughout this article, examples taken from the Finnish language interviews are provided with a translation into English.

Discourse analysis is used as an analytic tool to come to an understanding of how the policy setting for English-medium instruction is constructed in Finnish higher education. In 
analysing both the website data and the policy texts, occasions where English and other languages are made relevant, explicitly or implicitly, will be of particular interest. Equally important, however, is to be observant to absence of references to language use and learning because it may also be indexical of ideologies (e.g. Blommaert, 2010). Secondly, pilot interviews conducted among staff and students will illuminate to what extent their lived experiences meet the conditions and expectations emerging in the textual data.

\section{Historical background}

Internationalisation of Finnish higher education was until the Second World War directed towards Central Europe, with German as the main language of internationalisation (Saarinen, forthcoming). After the political, cultural and economic collapse of Germany in the Second World War, the direction of internationalisation within higher education turned towards Anglo-Saxon countries. English took over from German quite rapidly by the 1950s not only in Finland, but worldwide also in countries like Japan or Denmark, as a part of the post-war Pax Americana (Haberland, 2009).

Internationalisation did not, however, become a higher education policy issue until the late 1980 s, and was at that time geared mostly towards internationalisation of research and of staff and student exchanges. Finnish higher education became more decentralised as institutions received more autonomy and the old, detailed budget allocation financing gave way to a lump sum budgeting practice. State steering took another form, as institutions started receiving small performance based rewards in addition to the lump budgets. 'Internationalisation' made one part of the efficiency indicators; the others were quality, effectiveness and innovation. (Saarinen, 1997.)

In the early days of an institutionalised internationalisation policy, language skills were deemed important. Language Centres had been founded in universities during the degree reformation of the late 1970s. However, Ollikainen and Honkanen (1996: 72) argue that while languages featured relatively high in the internationalisation discourse of the early 1990s, languages were still referred to mechanistically or instrumentally, as self-evident. The first official internationalisation strategy was written in 1987 as an unpublished memo by the Ministry of Education. In the first strategy, language was frequently referred to in very practical terms, by discussing language skills of students and staff and by offering concrete suggestions for universities on how to improve their language provision.

Towards the end of the 1990s and especially beginning of the $2000 \mathrm{~s}$, the emphasis turned on developing 'foreign language' study programmes, as they were then called. As a consequence of the first policy for internationalisation (Ministry of Education, 1987), EMI programmes were set up; initially in the polytechnic sector, and after that in universities. At first, these were genuinely 'foreign language' programmes as the language repertoire of the programmes included also German and French in addition to English (see also the Dutch case in Wilkinson, this volume). 
The next internationalisation strategy of 2001 (Ministry of Education, 2001) made specific reference to the 'competitive edge' offered by English. 'English language' programmes were also referred to, but mostly reference was made to 'foreign languages'.

The latest internationalisation strategy for higher education was accepted in 2009 (Ministry of Education, 2009). Also this document refers systematically to 'foreign language' teaching, when, in fact, in Finnish higher education internationalisation, foreign means English (Lehikoinen, 2004).

That Finnish universities have so eagerly embraced opportunities to set up English medium degree programmes also reflects the strong role of English in Finnish society. It is studied widely and Finns' overall proficiency in English can be considered quite good, especially as regards the younger generations. Finns also encounter English daily in the media e.g. through films and TV series (that are subtitled rather than dubbed) and among the younger generations in particular, the use of resources from English may have various identity-related functions (see Leppänen \& al., 2008). Furthermore, Finns' attitudes to English are very positive, as indicated by a recent national survey on English in Finland, which also showed that the majority of respondents had favourable attitudes towards the idea of Finnish children attending English-medium schools (Leppänen \& al., 2009).

Hence, when teaching staff capable of teaching through a foreign language at university level is needed in Finland, it is obvious that the reserve for English-medium instruction is considerably larger than for any other foreign language (Ylönen,2011), which partly explains why international degree programmes are in the majority of cases offered in English. Another reason for the growing dominance of English over the last decades has to do with its role as the main international lingua franca in the academia, both in Finland and elsewhere (e.g. Mauranen, 2011; Smit, 2010).

The number of international degree programmes in Finnish higher education grew fast. In 1996, there were approximately 75 international programmes in universities and polytechnics; in 1999 this figure had almost doubled. In December 2010, there were 335 international degree programmes at Bachelor's and Master's level at universities and polytechnics, overwhelmingly in English. Two were run in Swedish (the other national language in Finland), and five in 'other' languages, which means Finnish and Finno-Ugric degree programmes offered for foreigners. Nowadays, measured by the share of English taught programmes against all programmes, Finland ranks second in Europe after the Netherlands. Measured by the proportion of institutions providing English language programmes, Finland ranks first in Europe (Wächter \& Maiworm, 2008).

\section{The role of language in describing the international degree programmes}




\section{Self-evident English}

Before turning attention to the websites of the degree programmes, it is worth reiterating that the more general context provided by the national level internationalisation policy documents frames the programmes in general terms as offered in a 'foreign language', despite the fact that the language is almost by definition English. For example:

The higher education institutions offer high-quality education focused on their fields of expertise, given in foreign languages (Ministry of Education, 2009: 26; our emphasis).

In order to improve the quality of education and counselling provided in a foreign language, the higher education institutions will focus on their continuing education activities for teachers and staff in language and cultural studies as well as the pedagogics of teaching in a foreign language (Ministry of Education, 2009: 20; our emphasis)

English is, in other words, clearly conflated (or euphemisized even, as implied by Lehikoinen, 2004) into 'foreign'. On the one hand, the choice of the more general term is probably indicative of a genuine political will to keep possibilities open for the introduction of other foreign language programmes. On the other hand, given that the spread of English also raises concerns relating to domain loss (Fishman, 1972; Haberland, 2005; see also Wilkinson in this volume), i.e. English gradually replacing the use of national languages in research and education (Hiidenmaa, 2003), the Ministry of Education as a national institution is in a precarious position when both national and international considerations need to be balanced and the scarcity of explicit references to English-medium programmes may reflect this. Hence, even when the strategy texts explicitly acknowledge the strong position of English, general reference is still made to 'foreign languages':

Higher education institutions have increased education given in foreign languages leading to a qualification. In proportion to the size of our higher education sector, there is an exceptionally large amount of teaching available in English (Ministry of Education, 2009: 14; our emphasis).

This ambivalence between 'foreign' and 'English' does not concern the websites analysed as all programmes are conducted in English. The role of English as almost self-evident in the context of international degree programmes is also reflected by many descriptions making no explicit reference to the language of instruction. Instead, the fact that the programme websites are in English seems to function as an index of the working language of the programmes as well. 
However, in many descriptions English as the working language is mentioned explicitly, typically early on when introducing the programme:

The language of instruction is English ( $\mathrm{TY}^{3}$ Law and Information).

The programme is conducted in English (JAMK Logistics engineering).

All courses are given in English (TuAMK Information Technology).

As the examples show, references to English provide factual information about the language of instruction and in no way point towards the programmes as arenas for learning (academic, field-specific) English. In other words, international degree programmes are not textually construed, and probably not perceived, as contexts for language learning. However, there is an exception as in the description of JY Mobile Technology and Business programme it is stated that upon completion of the programme, students will have obtained 'excellent communication skills due to the integrated language and communication studies'. Other than that, the role of English-medium programmes in higher education does not, at least explicitly, seem to fit into the realm of content and language integrated learning (CLIL) that has as its starting premise the simultaneous learning of both language and content. This probably reflects the point made by Smit (2010: 262) that, rather than language learning being the motivation for choosing the instructional language, the use of English in tertiary education usually derives from the fact that it is the only language that all participants share.

Curiously, the only time 'bilingualism' is mentioned as a learning object, it has to do with a novel and humoristic use of the term, as indicated by the quotation marks, to describe the simultaneously growing competences in two disciplinary areas:

Our mission is to educate 'bilingual' experts, in terms of combined knowledge of information technology and biosciences (TY Bioinformatics; our emphasis).

This finding of 'invisibility' of languages is also corroborated by the pilot interviews of university staff and students. During the interviews, none of the interviewees mentioned the language of studies independently without the initiation of the interviewer, as if language had nothing to do with the goals, everyday practices, difficulties and high points of international study and its organization. When language was mentioned in the student narrative (and on the initiation of the student writing it), it was in the context of studying other languages than Finnish or English (student, written narrative), and when referring to the importance of languages in general in international communications, with specific reference to the January 2011 events in North African Arabic countries (staff, university central administration, interview).

Implicit English: Discourses of internationalisation and globalisation 
Even if English, or languages in general, are rarely discussed explicitly when describing the degree programmes, the use of languages is brought in by implication through reoccurring references to internationalisation and globalisation. These two concepts by definition involve crossing national boundaries and interacting with people from different (language) backgrounds in both formal and everyday situations (Haberland, 2009). Interaction, in turn, necessitates the use of communicative resources of which language is undoubtedly a crucial one, hence the idea of languages implied.

Describing programmes as international/intercultural and global seems to serve a twofold function. Firstly, these labels are used in a promotional manner to define the learning environment and ways of working in the degree programmes, the implication being that the international and global atmosphere is a feature that distinguishes these programmes from regular courses offered in Finnish universities:

Education is given in English, and the students of this international programme learn to work together with associates from different countries and cultures (TY Environmental Sciences).

You will study in a multicultural group of students coming from different countries (JAMK Facility Management).

Learning is based on applying theoretical knowledge in a multicultural, innovative learning environment (JAMK International Business).

Secondly, the descriptions often make reference to the degree programmes preparing the students' global or international skills for a global and international future in the labour market:

To educate experts of research on institutions in an international, multidisciplinary environment. (TY Institutions and Social Mechanisms)

[...] you will be able to develop your intercultural business skills. We offer you excellent opportunities for creating a career in international companies. (JAMK Facility Management)

We strive to develop talent which will be capable to contribute to innovative companies' international expansion and lead their development. (TY Global Innovation Management)

The Degree Programme in International Business prepares you with the skills and knowledge to be successful in global business. (JAMK International Business) 
Accordingly, the staff in the pilot interviews tended to motivate international study specifically from the perspective of labour market needs. This is indicative of the change in motivations of internationalisation. Until the 1970s, internationalisation was largely motivated by humanistic values of international peace and solidarity; from the 1980s onwards, more utilitarian motivations such as economic and labour market benefits gained ground (Ollikainen \& Honkanen, 1996: 87-89; see also Wilkinson in this volume for the monetization period).

As far as policy texts are concerned, they also refer to the potential of international study programmes, and especially of the mobility involved, to increase intercultural skills as evidenced by a quote from the 2009 internationalisation strategy:

...mobility increases the competence needed for working in an international higher education community by improving the appreciation of other cultures, religions and languages.

In sum, globalisation and internationalisation in general but of the labour market in particular are prevalent themes used to motivate the international degree programmes. The role of language in this is not explicitly discussed, yet at the level of implication connections are forged between language (English), internationalisation and globalisation. Moreover, as shown by the following example, these descriptions may be combined with positive adjectives such as 'modern' and 'innovative',

... competences you gain will give you a great opportunity to work for modern, innovative, global companies (JAMK International Business).

The implicit connection of English to such clusters creates, discoursally and ideologically, a powerful image of their interdependency and makes the role of English as the de facto lingua franca of international programmes even stronger.

\section{The role of multilingualism and multiculturalism}

If learning English through attending courses offered in English is not an issue in the degree programme websites, learning other languages is even less so. On only a couple of occasions, shown below, language learning is brought up as an outcome of participating in international programmes; the second extract is exceptional in that specific languages are mentioned:

The studies include a comprehensive choice of economic sciences, other business and finance-related subjects and foreign languages (TY Global Innovation Management).

Our structure offers you also an excellent chance to develop your language skills and multicultural skills. We provide individual tutoring in English. You are expected to 
study other languages as well: Finnish, German, Russian, French, Italian, Spanish, Japanese, Chinese, etc. (JAMK International Business).

Students are encouraged to take language studies. The language studies can not replace the compulsory subject studies, but they can be included in the degree as additional studies (TY Baltic Sea Region Studies).

The Internationalisation strategy of 2009 seems to be more explicit in this regard, as the following example shows. Study and work abroad are assumed automatically to improve the students' language and cultural skills:

Studying and working abroad improve the individual's language skills and position in the labour market and increase understanding between cultures and societies.

$[\ldots]$

Moreover, mobility increases the competence needed for working in an international higher education community by improving the appreciation of other cultures, religions and languages.

As regards the interviews and the narrative, when interviewees and the writer of the narrative explicitly (and without prompting) refer to 'language', the mentions concern mastery or studying of other languages rather than focusing on English, as shown in the following examples:

The language centre offers a wide range of language courses, all of them are free to university students. We can choose whatever language courses that interest us. There are several different courses regarding any one single language. As a result students really have great freedom to choose the courses that suit them most. (Student, narrative)

This... Southern Mediterranean which at the moment is rather unpredictable in a way is kind of interesting in that $[\ldots]$ it may be something that will inevitably arise ... Arabic is not necessarily mastered too well by our students but there are French speakers, so they kind of do it with this transition (Staff, university central administration, interview; Finnish in the original. Our translation).

Despite these occasional references to the importance of learning and studying other languages, the overall impression remains that languages rarely become an issue either when international study programmes are described or when participating students and teachers offer accounts of their experiences in the increasingly international world of higher education. This 'invisibility' of language may reflect its self-evident nature, something so ingrained in the processes and practices of studying that it rarely ends up being discussed, let 
alone questioned. However, what also remains invisible is that underneath this self-evident surface, there may remain many important concerns relating to the role of different native languages in various contexts of study, on the one hand, and the role that different languages play in the entry and course requirements.

\section{The role of language in regulating access to the degree programmes}

It was shown above that the role of English and language in general remains marginal, or at least tends to be implicit rather than explicit, when the content and learning objectives of study programmes are described. However, when questions of eligibility and access become an issue, the role of English is very significant and explicit.

\section{What kind of English?}

As discussed above, the texts introducing the study programmes convey an impression that they are not perceived as environments for language learning. This is further emphasized by the fact that skills in English are usually stated as an important prerequisite for studying in the international degree programmes. In other words, good proficiency in English is something students must possess prior to their studies rather than develop along their studies, as evidenced by the following quotes about course requirements:

[...] a sufficient knowledge in English language is required (TY Biomedical engineering).

[...] a good command of English (TY Learning, Learning Environments and Educational Systems).

Excellent command of English (JY Educational Leadership).

To specify what counts as 'good' or 'sufficient' skills, all programmes have defined some minimum level of language skills, to be shown with a test that students must pass to prove their proficiency in English.

All polytechnics in our data have adopted the same language skill requirements since 2011. The tests accepted are usually TOEFL (for polytechnics, the score of 550 in paper based test/79-80 in Internet based text), IELTS (academic score 6.0), the National Certificate of Language Proficiency in English (skills level 4); also the minimum grade of C in advanced level English in the Finnish Matriculation examination, a school leaving examination in high school, counts as evidence of proficiency in English. These requirements approximate the B1/B2 levels of the Common European Framework of Reference (CEFR) ${ }^{4}$. 
The requirements are not equally unified in universities. Yet, in general, similar rules apply as with the polytechnics, but the test score limits are slightly higher, ranging from 575-600 in the TOEFL paper based test, or 79-92 in the Internet based test.

Good command of English is thus represented as a self-evident entry requirement for all students, for the obvious reason that the programmes are run in English. It is worth noting, however, that regardless the similar score limits, the level of skills is phrased in quite different terms, ranging from sufficient via good, very good and excellent to fluent. As the different adjectives seem to have no clear-cut connection to required scores in language proficiency tests, the range of adjectives is probably indicative of different emphases placed on the quality of language skills. Verbalising for instance 575 in the TOEFL paper based test as 'sufficient', 'good' or 'excellent' creates different horizons of expectation on language skills, and the verbalisation may either lower or heighten the entry threshold for the prospective student.

\section{Whose English?}

In addition to defining accepted language test scores, the programme descriptions also spell out who will be exempted from taking a language test. Here, we argue that entry qualifications shift from being purely related to language skills to having political implications.

As said above, since 2011, polytechnics have nationally unified language requirements. According to these, exempt from language tests are those who have completed upper secondary education or a university degree in English in the United Kingdom, Ireland, the United States of America, Canada, Australia or New Zealand. Moreover, a Bachelor's or Master's degree conducted in English in a European Union or European Economic Area (EU/EEA) country is also an accepted demonstration of sufficient English language skills.

Below are the current language skills requirements of polytechnics:

In 2011, all those applicants who are applying with a qualification completed somewhere else than in Finland and are not citizens of an EU/EEA-country, must provide a proof of language skill. Accepted certificates are:

* TOEFL score 550 paper based test/79-80 Internet based test

* IELTS academic score 6.0

* grade $\mathrm{C}$ in the Finnish Matriculation examination in advanced level English

* skills level 4 in English in the National Certificate of Language Proficiency. In addition upper secondary education or University degree in English completed in the United Kingdom, Ireland, the United States of America, Canada, Australia or New Zealand or a bachelor's or Master's degree conducted in English in a European Union or European Economic Area Country is also accepted as a demonstration of 
sufficient English language skills. Education in English completed in any other country will not be accepted. (http://www.admissions.fi)

As is seen from the above, education in English completed anywhere else than in the countries listed is explicitly not accepted. Thus, the emphasis is very much on recognised Anglo-American varieties of English. This leaves qualifications received in the approximately 50 countries where English is an official language (such as India, Pakistan, Nigeria, South Africa) outside the selection of accepted languages, creating a hierarchy of different Englishes.

For universities, however, the range of language criteria is wider, as universities have opted to keep the decision on language requirements to themselves. However, while universities do not have nationally unified language skill requirements, some harmonisation seems to be taking place, as can be deduced from the similar kinds of requirements within the same university, but also based on the pilot interviews with staff.

According to University Admissions Finland, a centralised organisation handling applications for international degree programmes for a number of Finnish universities, the students are usually exempt from the language test if their earlier studies have been completed "in English in Great Britain, Ireland, United States, Canada, Australia or New Zealand". The website also explicitly states:

Please note that education completed in English in any other country from the ones listed above does not give sufficient proof of English language skills. (http://www.universityadmissions.fi/)

Altogether 28 of 32 university programmes in our data will exempt applicants from an English test if they have had previous Bachelor level studies in one of the six English speaking countries mentioned above. Three out of the remaining four do not require a language test from 'native speakers'. However, only in one programme was nativeness defined by limiting it to the same six countries mentioned earlier; in the remaining two cases, nativeness was not specified in any way:

Native speakers (from USA, UK, Australia, New Zealand, Ireland and the English speaking part of Canada) do not have to send proof of language proficiency (TY Management of Information Technology).

The programme is conducted in English. All applicants who are not native speakers have to be able to demonstrate their English language proficiency at the time of the interview. The required level of English proficiency for the programme is equivalent to:

1) a TOEFL (Test of English as a Foreign Language) score of minimum 600 (paperbased) or 100 (internet-based) (www.toefl.org) 
2) an IELTS (academic) (International English Language Testing System) score of minimum 7.0 (www.ielts.org)

3) a Cambridge ESOL's Certificate of Proficiency in English (CPE) or Cambridge ESOL's Certificate in Advanced English (CAE) grade $\mathrm{C}$ or above (www.cambridgeesol.org)

4) a secondary level education diploma and Bachelor's degree studied in English, accompanied with a letter of verification from the awarding institution.

5) a Bachelor's degree certificate with the English language as a major. (JY / Educational Leadership

While the question of nativeness is not a major concern when defining eligibility, it seems to surface from time to time (see also Inbar-Laurie \& Donitsa-Schmidt in this volume). For example, one staff interviewee referred to nativeness in the programme as potentially problematic from the point of view of both teachers and students. There seem to be differences of opinion at least in the programme s/he represents as to whether there should be more native teachers or students on the one hand, or whether the students' English skills are adequate, on the other. As is typical for the interviews, the matter of language came up rather late in the interview (in this case, on the 54th minute), and on the initiation of the interviewer:

Interviewer: one more question here, we have been talking about internationalisation and different questions of culture, but not about language (Interviewee: $\mathrm{mmmm}$ ) How does... Do you think language is a factor here (Interviewee: nods slowly)... In what way?

Interviewee: Weeeel... It shows in that most of us ... teachers, me, students... none of us speak... or there are maybe one or two native English speakers (Interviewer: mmmmh). . But that all of us speak English as... non-native. And.. I don't know if it shows... well some teachers find it problematic that the students' English skills are not good enough ... but I think that's just something we have to be prepared for. That it's a part of the package (Staff, faculty level) (In Finnish in the original. Our translation).

In the extract, the focus of the potential problem of non-nativeness thus shifts from the lack of native speaking teachers and students to the apparently insufficient language skills of students, as perceived by the non-native teachers. (See also Cots and Doiz \& al. in this volume for further discussion on students' lack of English proficiency.)

In addition to the varieties of English used in contexts representing western countries and Anglo-American culture, there are other factors that may exempt the prospective university programme students from taking a standardised language test. Twelve out of 32 university programmes exempt students with a Bachelor's degree or similar in English from a European Union or European Economic area country. Furthermore, another three 
programmes give students with studies in English in a Nordic country exemption from test. The special rules for the European and Nordic countries perhaps suggest either a need to promote European and Nordic students, or that programmes in these countries are trusted over those in Asia or Africa. In this context, accepting studies in English in an European Union or European Economic area country as acceptable evidence of language skills makes 'EU English' (cf. Phillipson, 2003) both a political language variant and an indicator of adequate transparency and homogeneity of European higher education systems.

The governing rationality (Rose, 1996) of creating hierarchies between different varieties of English as accepted or non-accepted produces categories of identity, creating social order that fuels prestiged social trajectories. (Nikula \& al., forthcoming.) The mere use of English has been referred to as some kind of gatekeeping (Alexander, 2008: 83), but our examples above go beyond the gatekeeping role of English as the working language of the study programmes. By categorising different varieties of English, students are also categorised by what appears to be language criteria but what, in reality, can also be interpreted as a hierarchisation of the students' origins, language varieties, and the higher education systems they come from. These implicit requirements, or ascriptive characteristics (Hoffman, 2007) of nationality, educational background and language variety that are hidden behind the language requirements may sustain a certain level of inequality among international students.

\section{Conclusions}

In this chapter, we have explored the role of language in general and English in particular in how international, EMI programmes are described in the websites of Finnish universities and polytechnics and in Finnish policy documents dealing with internationalisation strategies of higher education. The university and national policy data has been complemented with four pilot interviews and an international student narrative.

Overall, the picture emerging is complex, with English appearing vital, even exotic from certain perspectives, and marginal or mundane from others. Firstly, as a starting point and the overall context for international study programmes, English plays a pivotal role: it appears the means that makes it possible for the educational institutions to strive towards the global, multicultural and international objectives set for higher education at policy level. While policy documents, euphemistically, make use of the label 'a foreign language' to describe the programmes, it is evident both on the basis of our textual data and of the Finnish educational scene in general that the de facto language of internationalisation is English.

Secondly, the role of English seems to increase in importance due to its role as a gatekeeper: Students' skills in English, and moreover, in a particular sort of English, become a major factor in regulating access to international study. We emphasise that requiring a particular skills level in English is in itself not problematic; on the contrary, it is a very practical 
requirement in international study contexts. However, emphasising a particular variety of English over another may produce different, probably unintended, categories of international students. Exempting students with a particular educational background from taking a language test not only selects students based on their language skills, but factually also based on their nationality, a particular set of Western hegemonic varieties of English, the status of the higher education system (as Anglo-American systems are preferred), or the status of the political system (as in some cases students within the European Union or European Economic are preferred).

Thirdly, when moving to the level of how international degree programmes are described on the homepages of universities and polytechnics or in policy documents, English acquires an almost taken-for-granted quality. It is the self-evident language of instruction and the shared lingua franca for multilingual and multicultural students and teachers. Given that proficiency in English is an entry requirement, its 'sufficient' or 'good' mastery after the entry seems to be presumed, with the consequence that the potential of the study programmes to further develop students' language skills does not become an issue. Policy documents do not discuss language learning, either, but forge (in a very unproblematic manner), a connection between international degree programmes and an increase in cultural, religious and language awareness and understanding.

Policy documents and degree programmes websites that at the same time function as advertisements for prospective students operate, by necessity, at a general level and obviously cannot focus on problematisations or take full stock of complexities involved in everyday practice. However, the image they create of the role of languages is indicative of a perception that does not take into consideration that language learning is part and parcel of any students' development into a professional and that instruction in a foreign language may add to this challenge (cf. Hellekjær, 2010). The self-evident role given to English, for its part, both further emphasizes its dominant role in the linguistic landscape of the academia, already a concern for many (see Lillis \& Curry, 2010), and also downplays the potential of multilingualism as a teaching and learning resource in international study programmes (see Kaloscai, 2009; Moore \& Dooly, 2010).

This chapter has illustrated that a global language entering national educational institutions is a precarious issue that creates controversies and tensions. Both educational authorities and higher education institutions are involved in a balancing act of sorts when they seek to embrace the benefits that international degree programmes bring without compromising the role of universities and polytechnics as national institutions. One way in which the struggle shows in the data analysed is the shifting role of English from invisibility to necessity.

\footnotetext{
${ }^{1}$ We approach the phenomena of internationalisation and globalisation textually, without preset definitions. However, for practical purposes, we find Teichler's (2004) definitions of 'internationalisation' as growing border-crossing activities between national systems of higher education, and 'globalisation' as increasing border-crossing activities of blurred national systems adequate.
} 
${ }^{2}$ While the Ministry of Education and Culture uses the word polytechnic when referring to institutions of vocational higher education, the institutions themselves prefer university of applied science. In this article, we use the simpler term polytechnic consistently, except when reference is made to their English name.

${ }^{3}$ We refer to the degree programmes by the institution's Finnish acronym and programme's name. Hence, TY $=$ University of Turku, JY = University of Jyväskylä, TuAMK = Turku University of Applied Sciences and JAMK = Jyväskylä University of Applied Sciences.

${ }^{4}$ According to an ETS summary of studies comparing IELTS, TOEFL and CEFR levels (Educational Testing Service, 2011), 79-80 (typical for polytechnics) on an internet based TOEFL test (TOEFL iBT) approximates a high B1 or a low B2 on the CEFR scale; and TOEFL iBT 79-92 (the range for universities) approximates a high B1 to a medium-range B2 on a CEFR scale. The IELTS score 6.0, often found in polytechnics' requirements, fits fairly well within B1 on the CEFR scale. IELTS score of 7.0, more found in the universities' requirements, more or less equals $\mathrm{B} 2$.

\section{References}

Airey, J. and Linder, C. (2006) Language and the experience of learning university physics in Sweden. European Journal of Physics 27 (3), 553-560.

Alexander, R. (2008) "International" programmes in the German speaking world and englishization: A critical analysis. In R. Wilkinson and V. Zegers (eds) Realizing Content and Language Integration in Higher Education (pp. 77-95). Maastricht: Maastricht University Language Centre.

Ammon, U. and McConnell, G. (2002) English as an Academic Language in Europe. A Survey of its Use in Teaching. Duisburg Papers on Language and Culture 48. Frankfurt am Main: Peter Lang.

Blommaert, J. (2010) A Sociolinguistics of Globalization. Cambridge: Cambridge University Press.

Coleman, J. (2006) English-medium teaching in European higher education. Journal of Language Teaching 39, 1-14.

Dafouz, E and Núñez, B. (2010) Metadiscursive devices in university lectures. A contrastive analysis of L1 and L2 teacher performance. In C. Dalton-Puffer, T. Nikula and U. Smit (eds) Language Use and Language Learning in CLIL (pp. 213-231). Amsterdam: John Benjamins.

Educational Testing Service (2011).Compare TOEFL ${ }^{\circledR}$ Scores, website, accessed September 10, 2011, http://www.ets.org/toefl/institutions/scores/compare.

Fishman, J. (1972) Domains and the relationship between micro- and macrosociolinguistics. In J. J. Gumperz and D. Hymes (eds), Directions in Sociolinguistics. The Ethnography of Communication (pp. 435-453). New York: Holt, Rinehart and Winston.

Haberland, H. (2005) Domains and domain loss. In B. Preisler, A. Fabricius, H. Haberland, S. Kjærbeck and K. Risager, K. (eds), The Consequences of Mobility: Linguistic and Sociocultural Contact Zones (pp. 227-237). Roskilde: Roskilde University. 
Haberland, H. (2009) English - the language of globalism? Rask, Internationalt Tidsskrift for Sprog og Kommunikation 30, 17-45.

Hellekjær, G. (2010) Language matters. Assessing lecture comprehension in Norwegian English-medium higher education. In C. Dalton-Puffer, T. Nikula and U. Smit (eds.) Language Use and Language Learning in CLIL (pp. 233-258).Amsterdam: John Benjamins.

Hiidenmaa, P. (2003) Suomen kieli - who cares? [The Finnish language - who cares?] Helsinki: Otava.

Hoffman, D. (2007) The Career Potential of Migrant Scholars in Finnish Higher Education: Emerging Perspectives and Dynamics. Jyväskylä: University of Jyväskylä.

Hughes, R. (2008) Internationalisation of higher education and language policy: Questions of quality and equity. Higher Education Management and Policy 20 (1), 111-128.

Kaloscai, K. (2009) Erasmus exchange students: A behind-the-scenes view into an ELF community of practice. Apples - Journal of Applied Language Studies, 3 (1), 25-49.

Lehikoinen, A. (2004) Foreign-language-medium education as national strategy. In R. Wilkinson (ed) Integrating Content and Language: Meeting the Challenge of a Multilingual Higher Education (pp. 41-48). Maastricht: Universitaire Pres.

Leppänen, S., Kääntä, L. and Nikula, T. (2008) Kolmas kotimainen. Lähikuvia englannin käytöstä Suomessa.[Third domestic language. Case studies of English in Finland]. Helsinki: Suomalaisen Kirjallisuuden Seura.

Leppänen, S., Pitkänen-Huhta, A., Nikula, T. Kytölä, S., Törmäkangas, T., Nissinen, K., Kääntä, L., Virkkula, T., Laitinen, M., Pahta, .P, Koskela, H., Lähdesmäki, S. and Jousmäki, H. (2009) Kansallinen kyselytutkimus englannin kielestä Suomessa: Käyttö, merkitys ja asenteet. [National survey of English in Finland: Uses, functions and attitudes]. Jyväskylä: Jyväskylä Studies in Humanities 132.

Lillis, T. and Curry, M. J. (2010) Academic Writing in a Global Context: The Politics and Practices of Publishing in English. London: Routledge.

Mauranen, A. (2011) English as the lingua franca of the academic world. In D. Belcher, A. M. Johns and B. Paltridge (eds) New Directions in English for Specific Purposes Research (pp. 94-117). Ann Arbor: Michigan University Press.

Ministry of Education (1987) Development of International Activities in Higher Education. Unpublished memorandum, Ministry of Education.

Ministry of Education (2001) Korkeakoulutuksen kansainvälisen toiminnan strategia. [International strategy of higher education institutions]. Helsinki: Ministry of Education.

Ministry of Education (2009) Strategy for the Internationalisation of Higher Education Institutions in Finland 2009-2015. Helsinki: Ministry of Education.

Moore, E. and Dooly, M. (2010) "How do the apples reproduce (themselves)?" How teacher trainees negotiate language, content, and membership in a CLIL science education classroom at a multilingual university. Journal of Language, Identity, and Education, 9, 58-79.

Nikula, T., Saarinen, T., Pöyhönen, S. and Kyllönen, T. (forthcoming) Linguistic diversity as problem and resource: Multilingualism in European and Finnish policy documents.J. 
Blommaert, S. Leppänen, P. Pahta and T. Virkkula (eds.). Dangerous Multilingualism. Palgrave.

Ollikainen A. and Honkanen, O. (1996) Kosmopoliittien kilpakenttä. Näkökulmia korkeakoulutuksen kansainvälisyyteen [Competition of cosmopoles. Views into internationalization of higher education].Turku: Turun yliopisto.

Phillipson, R. (2003) English-only Europe? Challenging Language Policy. London: Routledge.

Rose, N. (1996) Governing "advanced" liberal democracies. In A. Barry, T. Osborne and N. Rose (eds) Foucault and Political Reason. Liberalism, Neo-liberalism and Rationalities of Government (pp. 37-64).London: University College London Press.

Saarinen, T. (1997) Tehokkuudesta laatuun ja vaikuttavuuteen: tuloksellisuudesta palkitseminen Suomessa [From efficiency to quality and effectiveness: rewarding for results in Finland]. In K. Nyyssölä and T. Saarinen (eds) Näkökulmia korkeakoulutuksen tuloksellisuuteen (pp. 33-51). Turku: Turun yliopisto.

Saarinen, T. (forthcoming) Internationalisation of Finnish higher education - is language an issue? International Journal of the Sociology of Language, forthcoming.

Smit, U. (2010) CLIL in an English as a lingua franca (ELF) classroom: On explaining terms and expressions interactively. In C. Dalton-Puffer, T. Nikula and U. Smit (eds.) Language Use and Language Learning in CLIL (pp. 259-278). Amsterdam: John Benjamins.

Teichler, U. (2004) The changing debate on internationalisation of higher education. Higher Education 48, 5-26.

Vertovec, S. (2007) Super-diversity and its implications. Ethnic and Racial Studies 30 (6), 1024-1054.

Ylönen, S. (2011) The Role of languages at Finnish Universities. Apples - Journal of Applied Language Studies 5(3), forthcoming.

Wächter, B. and Maiworm, F. (2008) English-Taught Programmes in European Higher Education. The Picture in 2007. ACA Papers on International Cooperation in Education. Bonn: Lemmens. 